(u)

\title{
Application Effect of PhET Virtual Laboratory and Real Laboratory on the Learning Outcomes of Class XI Students on Elasticity and Hooke's Law
}

\author{
Zulkifli $^{1 *}$, Azhar ${ }^{1}$, Dina Syaflita ${ }^{1}$ \\ ${ }^{1}$ Departement of Physics Education Faculty of Teacher Training and Education, Riau University, Pekanbaru, Indonesia
}

DOI: $10.29303 /$ jppipa.v8i1.1274

\section{Article Info}

Received: December 26, 2021

Revised: January 25, 2022

Accepted: January 28, 2022

Published: January 31, 2022

\begin{abstract}
Physics is a scientific field that studies a lot of abstract concepts which in the learning process demands a lot of ability to do mental depictions of something being studied. This study aims to describe the cognitive learning outcomes of students who apply PhET virtual laboratory and Real Laboratory on elasticity and Hooke's law. The subjects of this study were two classes totaling 70 students of class XI MIPA SMA Negeri 2 Pekanbaru. This research uses quasi-experimental research with a quantitative approach and tests (pre-test and post-test) as data collection methods. To analyze the data, several analyzes were used, namely descriptive analysis (Absorption Power, Learning Effectiveness and Normal Gain Test) and Inferential analysis (t-test). The results showed that the average value of the pre-test class that implemented the PhET virtual laboratory was 44.40 and the post-test score was 76.20 , while the average value of the pre-test class that implemented the Real Laboratory was 43.80 and the score was 43.80 , post-test was 84.20 . The absorption category achieved by the two classes is in the same category, namely good and the effectiveness of the learning used is in the effective category. This shows that the learning outcomes of the two classes have increased with the average gain test being classified in the moderate criteria, namely 0.54 and 0.70 . In summary, the use of PhET Virtual Laboratory and Real Laboratory has a significant effect on students' cognitive physics learning outcomes. PhET Virtual Laboratory and Real Laboratory are effective for teaching Elasticity and Hooke's Law as an alternative to physics experimental activities.
\end{abstract}

Keywords: Elasticity and Hooke's Law; Physics learning outcomes; PhET Virtual Laboratory; Real Laboratory

Citation: Zulkifli, Z., Azhar, A., \& Syaflita, D. (2022). Application Effect of PhET Virtual Laboratory and Real Laboratory on the Learning Outcomes of Class XI Students on Elasticity and Hooke's Law. Jurnal Penelitian Pendidikan IPA, 8(1), 401-407. https://doi.org/10.29303/jppipa.v8i1.1274

\section{Introduction}

Natural science (IPA) is a way of systematically understanding nature, mastering knowledge, facts, concepts, principles, discovery processes, and having scientific insight (Religia, 2017). Science is not only the mastery of knowledge in the form of facts, concepts, or principles but also a process of discovery (Khairunnisyak, 2018). To master and understand science cannot be separated from observation or laboratory experiments.
Physics learning has a very important role for improve the quality of a nation. Physics learning is directed to the goal is that students can develop skills intellectually, think critically, logically, and scientifically and able to understand the concept, and solve problems especially those that related to everyday life. To achieve this goal, teachers must be skilled in choosing suitable models and media to be applied in the classroom (Siswadi, et al., 2016). Physics is a scientific field that studies a lot of abstract concepts which in the learning process require a lot of ability to do mental depictions of 
something being studied (Azhar, 2013). Science, especially physics, is a process and product, a process that refers to the stages/procedures for finding physical products (facts, concepts, principles, theories, or laws) which are carried out through scientific steps (Hanna, et al., 2017).

In science, one of the important aspects in finding applicable principles or laws is observation or observation of events, which includes the design and implementation of experiments (Giancoli, 2014). This is because, through experimental activities, students do think and also work on their hands. Familiarizing students in formulating, facing, and solving problems is one way to achieve mastery of a concept becomes better (Siti, et. al., 2016). Experimental activities in learning physics have a motivational role in learning, provide opportunities for students to develop a number of skills, and improve the quality of student learning outcomes. The success of learning physics in schools does not only depend on the good formulation of the applicable curriculum or syllabus but is also supported by the availability of adequate learning suggestions. To develop aspects of the process and aspects of scientific attitude, it is necessary to carry out experimental (demonstrative) activities on the material being studied (Azhar, 2013). The advantage of the experimental method is that it can make students more confident in truth or conclusion based on their own trials rather than just accept the teacher's words or read a book, students can develop attitudes to conduct better exploratory studies (Istiqomah, et al., 2016)

In physics learning generally, the problem that arises is the lack of understanding of the material presented by the teacher. This problem influenced by teacher-centered learning and lack of variety in learning, so as to make students are less active in gaining knowledge (Rumansyah, et al., 2016). The teacher is a determinant in instilling concepts into students, so that the teacher's mastery of the subject matter, the ability to choose and use learning models and techniques as well as the teacher's ability to determine learning media greatly determine the success of the learning process in addition to the potential and abilities of students (Rohwati, 2012). Based on the results of field research conducted by Mustachfidoh (2013) states that the learning process in the classroom is more directed at students memorizing information without being required to understand and develop information that is remembered in everyday life.

Traditional educational methods are carried out through face-to-face teaching where knowledge and learning are all regulated by the teacher. Some of these traditional learning methods and materials are effective, but there is increasing interest among educators and researchers to introduce a more useful method for enhancing the learning and teaching experience
(Herfana, et al. 2019). The knowledge transfer process in the classroom is one-way, causing students to get bored and have difficulty understanding lessons, especially abstract physics material (Doyan, et al., 2018). Teaching and learning interactions in the classroom cannot be separated from the media used by the teacher in delivering teaching materials. The use of appropriate learning media in the teaching and learning process can generate new desires and interests of students, generate motivation stimulate learning activities, and even provide psychological effects for students (Azhar, et al., 2021).

The laboratory has a very important role in learning Physics. Students' laboratory activities can be trained and equipped with several skills such as measuring, communicating, interpreting data, and making conclusions (Masril, et al., 2018). Laboratory-based science learning is one of experimental learning which means that science learning, especially physics, will be better if it is supported by experimental activities by the teacher or the students themselves in a guided laboratory in the laboratory (Hartina, et al., 2019). From the results of Arista, et al., (2013) research that physics teachers tend not to use physics laboratories optimally, for example, teaching aids and practicum, but teachers only teach theory and lectures in class, so students find it difficult to understand physics subject matter which is generally general in nature experiment.

Based on observations made at SMAN 2 Pekanbaru, the tendency of learning implementation is still teachercentered and reading books. The implementation of physics learning still uses the lecture method (the teacher as a learning resource), students only take notes from reading books and work on the questions on the student worksheet individually. Such learning tendencies result in the weak development of students' self-potential in learning so that the learning achievement achieved is less than optimal. Learning physics using practicum is still rarely implemented. Some of the reasons put forward include: learning with practicum takes a lot of time and energy, the implementation of the practicum is not assisted by laboratory assistants or laboratory technicians, and others.

One of the physics materials that require reasoning through practicum is the material on Elasticity and Hooke's Law in class XI. Materials on Elasticity and Hooke's Law include physics materials that require simple experiments in discovering applicable principles and theories so that student competency achievement becomes better.

Overcoming this in conducting practicals can be done by carrying out simple experiments through the laboratory. One alternative laboratory that allows to supports the learning process is a learning system using a virtual laboratory. To improve students' scientific 
skills, especially in practical material, the learning strategy must undergo several changes. One learning approach that is suitable to be applied is virtual laboratory-based learning (Ratih, et al., 2020). According to Lerianti (2014), "Virtual Laboratory is a series of laboratory tools in the form of interactive multimedia-based computer software, which is operated with a computer and can simulate activities in the laboratory as if the user was in a real laboratory". With the virtual laboratory, students are expected to be able to do practicum independently or in groups without fearing that the equipment will be damaged or run out. Virtual class or e-learning is a form of internet use that is able to facilitate students in the learning process. The use of virtual classes is currently an interesting thing for many users, especially educators, who are almost entirely using Android-based smartphones (Sari, et al., 2021). To support the learning process, in this study two kinds of laboratories were used, namely virtual laboratories and real laboratories.

Lab-Vir can be defined as a series of computer programs that can visualize abstract phenomena or complex experiments carried out in real laboratories, thereby increasing learning activities in an effort to develop the skills needed in problem-solving (Yusuf and Subaer, 2013). A virtual laboratory is an interactive simulation software specially designed for experimental activities. According to Munir (2012), simulation is artificial that resembles real conditions and situations or doing real exercises without having to face actual risks. With this simulation, students can collect data quickly in any situation without fear of damage to the tool. With the existence of a virtual laboratory, students are more flexible independently or in groups to carry out practicals without fear of the equipment being damaged or running out. Practicum can also be carried out even though the tools in the physical laboratory are not available and there is no longer any reason for teachers not to carry out practical activities, it can even be an alternative for schools that do not have laboratory facilities so that students' scientific work competence can be achieved.

The learning process can be supported by the presence of computer simulation media that can reduce the real state of scientific phenomena. One of the easiest simulation media to download is PhET (Physics Education Technology (Suporwoko, et al., 2017). The PhET Interactive Simulation developed by the University of Colorado Boulder provides dynamic access and represents hard-to-see things in real experiments, making investigations fun for students. The advantage offered by the PhET simulation is that it can be accessed and downloaded free of charge on the $h t t p: / / P h E T . c o l o r a d o . e d u$ and can be used without being connected to the internet (Hidayati and Masril, 2019). The purpose of making this software is to help students visualize concepts completely and clearly, then ensure effective education and continuous usability. The use of a virtual PhET laboratory can make it easier for students to understand physics materials that are concrete or abstract.

The term real laboratory is used to describe a laboratory that has a real form, which is a place in which there are all tools and materials that are really real to be used for the purposes of practical activities. According to Budiyono, (2009), a real laboratory is a special place laboratory that is equipped with real tools and materials to conduct experiments (practicums) in physics, chemistry, or biology. In general, this laboratory is used in schools or universities to carry out practical activities.

\section{Method}

This study uses a Quasi-Experiment research type. The research design used is the Randomized PretestPosttest Group Design, which is a research design in which the sample is taken randomly from a homogeneous population. The place of research was carried out at SMA Negeri 2 Pekanbaru. The time of the implementation of this research is in the academic year 2021/2022 odd semester from July-November 2021.

The population in this study were students of class XI MIPA SMA Negeri 2 Pekanbaru in the odd semester of the 2021/2022 academic year which consisted of 4 classes. Sampling in this study using a random sampling technique. The research sample was taken randomly from two classes that have equal ability without randomizing the students in their class. Equality between the two classes can be seen from the results of the students' final exams in the previous semester with normality and homogeneity tests. then obtained class XI MIPA 4 as the experimental class I which implemented a virtual PhET laboratory with 35 students and class XI MIPA 3 as the experimental class II which implemented the Real laboratory with 35 students. Figure 1 is a chart of the research used.

In the process of data collecting, the technique used by the researcher was in the form of a test of students' cognitive physics learning outcomes in the form of pretest and post-test given before and after treatment. The data analysis technique used in the form of descriptive data analysis is seen from the average absorption, learning effectiveness, and Normal Gain Test, as well as using inferential analysis with t-test. After being processed, then the cognitive physics learning outcomes of the two experimental classes were tested using the independent test, the $t$-test was used to determine the difference in cognitive physics learning outcomes of students who apply PhET virtual laboratory and real laboratory. 


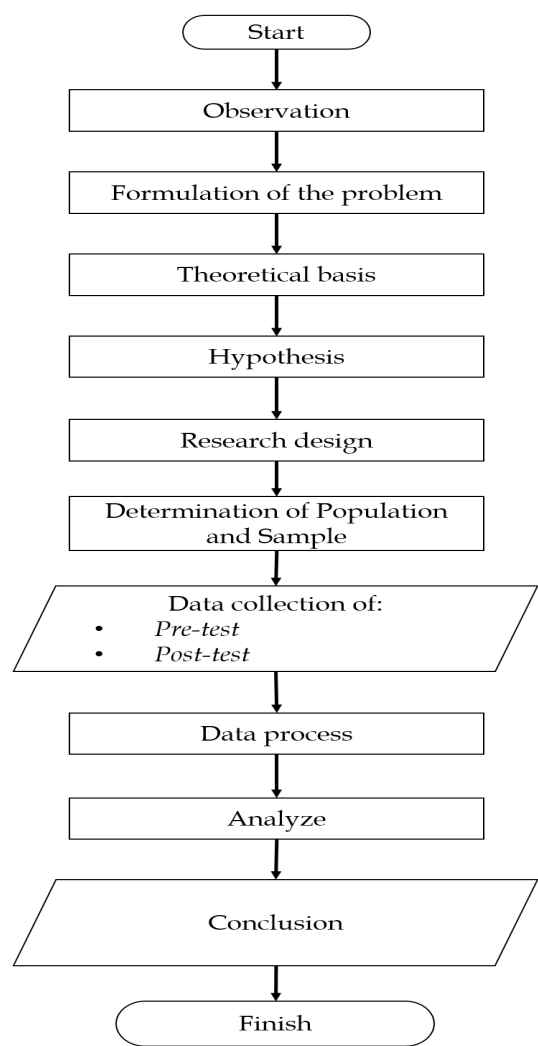

Figure 1. Flowchart of Method

\section{Result and Discussion}

Research on the effect of the application of the virtual PhET laboratory and real laboratory on the learning outcomes of class XI students on the subject of Elasticity and Hooke's Law at SMAN 2 Pekanbaru, there are two variables. The independent variable is "PhET virtual laboratory and real laboratory", while the dependent variable is "Cognitive learning outcomes".

The data analyzed in this study is the data on cognitive physics learning outcomes for students in the experimental class I and experimental class II. Data on students' cognitive physics learning outcomes were obtained from the posttest results which were carried out after the implementation of the PhET virtual laboratory in experimental class I and the real laboratory in experimental class II.

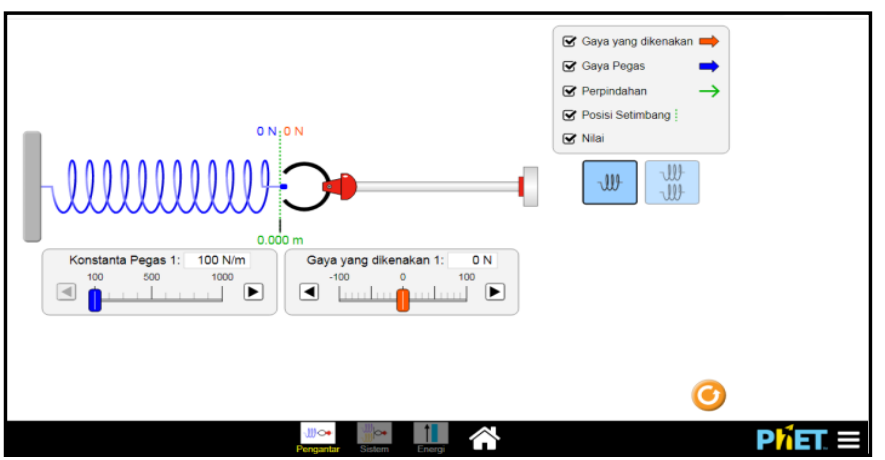

Figure 2. PhET virtual laboratory
After learning is done using a virtual PhET laboratory and a real laboratory, it was found that the students' absorption for each indicator in experimental class I and experimental class II varied.

Table 1. Average Absorption and Learning Effectiveness

\begin{tabular}{lcccc}
\hline $\begin{array}{l}\text { Aspects of } \\
\text { Descriptive } \\
\text { Analysis }\end{array}$ & \multicolumn{2}{c}{ Experimental Class I } & \multicolumn{2}{c}{ Experimental Class II } \\
\cline { 2 - 3 } $\begin{array}{l}\text { Average } \\
\text { Absorption } \\
\text { Learning } \\
\text { Effectiveness }\end{array}$ & 76.20 & Good & 84.20 & Good \\
\hline description: & & Effective & 84.20 & Effective \\
\hline
\end{tabular}

description:

Experimental Class I: Apply the PhET virtual Laboratory Experimental Class II: Apply the Real Laboratory

Based on the results of data analysis, it was obtained that the average absorption of students in the experimental class II which implemented a real laboratory was higher than the experimental class I which applied the Virtual PhET laboratory. This is shown in experimental class I the average absorption of students reached $84.2 \%$ and the experimental class II $76.4 \%$. The percentage of average absorption of experimental class I and experimental class II is in the same category that is good, but the average absorption power of experimental class II is higher than that of experimental class I with a difference of $8 \%$ in value.

The effectiveness of learning through the application of PhET virtual laboratories and real laboratories refers to the average absorption value of students in the experimental class I and experimental class II. From the average absorption value of students obtained, the effectiveness of learning in experimental class I and experimental class II are in the same category, namely effective.

After seeing student absorption and learning effectiveness, to see how the students' cognitive physics learning outcomes improve, they can use the Normal Gain Test. The Normal Gain test was carried out to see the category of increasing cognitive physics learning outcomes for students in experimental class I and Experiment class II by calculating the difference between the pretest and posttest results obtained by students.

Table 2. Normal gain test results

\begin{tabular}{lllll}
\hline Sample Data & $\begin{array}{l}\text { Mean } \\
\text { Value of } \\
\text { pretest }\end{array}$ & $\begin{array}{l}\text { Mean } \\
\text { Value of } \\
\text { Posttest }\end{array}$ & $\begin{array}{l}\text { Mean of } \\
\text { Normal } \\
\text { Gain }\end{array}$ & Category \\
\hline $\begin{array}{l}\text { Experimental } \\
\text { Class I }\end{array}$ & 44.40 & 76.20 & 0.54 & Medium \\
\hline $\begin{array}{l}\text { Experimental } \\
\text { Class II }\end{array}$ & 43.80 & 84.20 & 0.70 & Medium \\
\hline
\end{tabular}

Based on Table 2, the increase in student learning outcomes obtained from the average score of Normal 
Gain is both in the medium category. The experimental class I obtained a Normal Gain score of 0.70 while the experimental class II obtained an average Normal Gain score of 0.54. However, experimental class II had a slightly larger improvement score than experimental class I with a difference of 0.24 . This result means that the increase in cognitive physics learning outcomes of experimental class II students who apply a real laboratory on elasticity and Hooke's Law is better than a class that applies a PhET virtual laboratory.

After the descriptive analysis was carried out, it was followed by an inferential analysis using the t-test. Before conducting the inferential analysis, the researcher conducted a normality test which aims to determine whether the data distribution is normal or not. After the normality test was carried out, the researcher continued for the homogeneity test which aims to determine whether the data distribution is homogeneous or not.

Based on the data obtained by the normality test, the pretest data from experimental class I was 0.70 and the experimental class II was 0.136. The pretest normality test for the two experimental classes had a significance value of 0.05 , so it can be concluded that the pretest data for experimental class I and experimental class II were distributed. normally. Then the posttest data normality test for the experimental class I was 0.054 and the experimental class II was 0.076, the posttest normality test for both classes had a significance value of 0.05 , so it can be concluded that the post-test results for the experimental class I and the experimental class II were normally distributed.

After the data obtained from the pretest-posttest results of the experimental class I and the experimental class II were normally distributed, then the next test was the homogeneity test which was carried out using SPSS 25. experimental class II has a significance value of 0.05 . So, we can conclude that the experimental class I and experimental class II data are homogeneously distributed.

After the prerequisite test is met, hypothesis testing is carried out. Hypothesis testing on parametric statistics using the t-test technique. Testing this hypothesis is done through the Independent-Sample T-Test. After obtaining $t_{\text {count, }}$ then it is compared with the distribution of $t_{\text {table. }}$.

Based on the Independent Sample T-Test test on SPSS 25, it was found that the students' cognitive physics learning outcomes obtained $t_{\text {count }}$ of -2.805 with $\mathrm{df}$ of 68 and $t_{\text {table }}$ of -1.667 . The results of hypothesis testing indicate that $t$ table $t_{\text {count }}$ or $-1.667>-2.805$, it can be stated that $\mathrm{HO}$ is rejected and $\mathrm{Ha}$ is accepted at the 95\% confidence level. It can be interpreted that there is a significant difference in learning outcomes between the class that implements the virtual PhET laboratory and the class that implements the real laboratory in class XI MIPA SMA Negeri 2 Pekanbaru.
Based on the results of data analysis carried out, it shows that the average score of student learning outcomes in experimental class II using a real laboratory is higher than the experimental class I using a virtual PhET laboratory. This achievement of learning outcomes can be caused by learning to use a real laboratory in the learning process, its use is included in the effective category. The direct role of students in conducting practicals with real equipment shows that most students are more enthusiastic in participating in learning so that student learning outcomes are obtained higher than the learning outcomes of students who use PhET virtual laboratories.

Learning by applying real laboratories provides opportunities for students to share ideas and consider experimental results better. In addition, the experimental class II students have an interest in conducting experiments because they have never conducted experiments using a real laboratory before. Direct learning experiences through real laboratories will produce knowledge that is easy to remember and understand and lasts a long time. This is in accordance with research conducted by Putri, (2018) which states that classes that apply real experiments are more effective in increasing mastery of concepts than virtual ones. Harmonious research also proves that learning to apply to real laboratories provides opportunities for students to share ideas and consider the most appropriate answer to a problem given by the teacher (Kadir, 2014).

Meanwhile, the implementation of the Virtual PhET laboratory has lower cognitive physics learning outcomes. This is due to various weaknesses that cause students to be less focused in participating in learning. When the learning activities took place, many students were not used to using the PhET virtual laboratory independently because previously students had never experimented with a real laboratory so students had difficulty operating and assembling the tools found in the virtual PhET laboratory. In addition to the difficulty of students in assembling the tools and materials contained in the PhET virtual laboratory, several other factors that cause students to be less focused when learning are as follows: First, the use of the PhET virtual laboratory requires students to always be connected to the internet, so that during the experimental activities, the internet connection sometimes disconnects and causes student experiments to take longer. Second, the use of the PhET virtual laboratory is accessed through each student's smartphone, which causes researchers as teachers to find it difficult to control students who freely open pages other than the PhET virtual page, this affects students' focus in understanding the concept of the experiment being carried out. 


\section{Conclusion}

Based on the results of the descriptive and inferential analysis conducted on students' cognitive physics learning outcomes on Elasticity and Hooke's Law in class XI SMA Negeri 2 Pekanbaru, the conclusions that can be drawn are as follows: First, The application of a virtual PhET laboratory and a real laboratory can improve students' cognitive learning outcomes on the subject of Elasticity and Hooke's Law in class XI of SMA Negeri 2 Pekanbaru with the category of student absorption in the experimental class I and Experiment II is good and the category of learning effectiveness by applying the PhET virtual laboratory and real laboratories are effective. Second, the increase in cognitive learning outcomes in classes that apply PhET virtual laboratories and real laboratories are both in the moderate category. The tendency to improve cognitive learning outcomes is better in classes that apply to real laboratories. Third, there is a significant difference in student learning outcomes between classes that apply the PhET virtual laboratory media and classes that apply real laboratory media to the materials of Elasticity and Hooke's Law.

Thus, the application of a virtual PhET laboratory and a real laboratory is effective in improving students' cognitive learning outcomes on the subject of Elasticity and Hooke's Law in class XI of SMA Negeri 2 Pekanbaru.

\section{References}

Arista, S., Nasir, M., \& Azhar, A. (2013). Analisis Kesulitan Belajar Fisika Siswa Sekolah Menengah Atas Negeri Se-Kota Pekanbaru. Repository Unri. Universitas Riau. Retrieved from https://repository.unri.ac.id/handle/123456789/ $\underline{3643}$

Azhar, A. (2013). Pendidikan Fisika Dan Keterkaitannya Dengan Laboratorium. Jurnal Geliga Sains: Jurnal Pendidikan Fisika, 2(1), 7-12. Retrieved from https://jgs.ejournal.unri.ac.id/index.php/JG S/article/view/1582

Azhar, Herfana, P., Nasir, M., Irawan, D., \& Islami, N. (2021). Development of 3D Physics Learning Media using Augmented Reality for First-year Junior High School Students. Journal of Physics: Conference Series, 2049(1), 012036. https://doi.org/10.1088/17426596/2049/1/012036

Budiyono. (2009). Penerapan Laboratorium Riil Dan Virtual Pada Pembelajaran Fisika Melalui Metode Eksperimen Ditinjau Dari Gaya Belajar. Tesis. Program Pascasarjana Universitas Sebelas Maret.

Doyan, A., Taufik, M., \& Anjani, R. (2018). Pengaruh Pendekatan Multi Representasi Terhadap Hasil Belajar Fisika Ditinjau Dari Motivasi Belajar Peserta
Didik. Jurnal Penelitian Pendidikan IPA,4(1). https://doi.org/10.29303/jppipa.v4i1.99

Giancoli, D.C. (2014). Fisika: Prinsip dan Aplikasi (terjemahan). Jakarta: Erlangga.

Hanna, D., Sutarto, S., \& Harijanto, A. (2017). Model Pembelajaran Tema Konsep Disertai Media Gambar Pada Pembelajaran Fisika Di SMA. JURNAL PEMBELAJARAN FISIKA, 5(1), 2329.

Retrieved from https://jurnal.unej.ac.id/index.php/JPF/arti cle/view/3558

Hartina, L., Rosidin, U., \& Suyatna, A. (2020). Pengaruh Penerapan Instrumen Performance Assessment pada Pembelajaran IPA Berbasis Laboratorium Real terhadap Hasil Belajar Siswa. Jurnal Penelitian Pendidikan IPA, 6(1), 25-31. https://doi.org/10.29303/jppipa.v6i1.299

Herfana, P., Nasir, M., Azhar, \& Prastowo, R. (2019). Augmented Reality Applied in Astronomy Subject. Journal of Physics: Conference Series, 1351, 012058. https://doi.org/10.1088/17426596/1351/1/012058

Hidayati, H., \& Masril, M. (2019). Penggunaan LKM Untuk Menunjang Kegiatan Laboratorium Virtual Fisika Inti. Jurnal Penelitian Pendidikan IPA, 5(2), 149-153. https://doi.org/10.29303/ippipa.v5i2.250

Inriani, I., Azhar, A., \& Nasir, M. (2021). Development of Learning Devices Using Creative Problem Solving (CPS) Models on Static Electricity Material. Jurnal Penelitian Pendidikan IPA, 7(SpecialIssue), 213-217. https://doi.org/10.29303/ippipa.v7iSpeciallssue.1 $\underline{119}$

Istiqamah, N., Doyan, A., \& Taufik, M. (2016). Pengaruh Model Pembelajaran Discovery Dan Inkuiri Terbimbing Berbasis Eksperimen Terhadap Hasil Belajar Fisika Dan Sikap Ilmiah Siswa. Jurnal Penelitian Pendidikan IPA, 2(1). https://doi.org/10.29303/jppipa.v2i1.30

Jannah, S. N., Doyan, A., \& Harjono, A. (2016). Pengaruh Model Pembelajaran Kooperatif Dengan Pendekatan Problem Posing Ditinjau Dari Pengetahuan Awal Terhadap Penguasaan Konsep Fisika Siswa Smk. Jurnal Penelitian Pendidikan IPA, 2(1). https://doi.org/10.29303/jppipa.v2i1.29

Kadir, A. R. (2014). Perbandingan Efektivitas Penggunaan Laboratorium Riil Dengan Laboratorium Virtual Terhadap Hasil Belajar Peserta Didik Pada Pokok Bahasan Sistem Ekskresi Kelas Xi IPA SMAS Rahmatul Asri Kabupaten Enrekang. Repositori. UIN Alauddin. Retrieved from alauddin.ac.id/id/eprint/2165

Khaerunnisak, K. (2018). Peningkatan Pemahaman Konsep Dan Motivasi Belajar Siswa Melalui Simulasi Physic Education Technology 
(PhET). Jurnal Penelitian Pendidikan IPA, 4(2). https://doi.org/10.29303/jppipa.v4i2.109

Lerianti, E. (2014). Perbandingan Hasil Belajar dengan Menggunakan Laboratorium Nyata dan Laboratorium Virtual dalam Materi Asam Basa Kelas X IPA SMA Nusantara Kota Jambi. Skripsi. Jambi: Universitas Jambi.

Masril, M., Hidayati, H., \& Darvina, Y. (2018). Penerapan Discovery Learning Berbantuan Virtual Laboratory Untuk Meningkatkan Kompetensi Fisika Siswa Sma. Jurnal Penelitian Pendidikan IPA, 5(1). https://doi.org/10.29303/jppipa.v5i1.160

Munir. (2012). Multimedia Konsep \& Aplikasi dalam Pendidikan. Bandung: Alfabeta.

Mustachfidoh, M., Swasta, IBJ., \& Widiyanti, N.L.P.M. (2013) Pengaruh Model Pembelajaran Inkuiri Terhadap Prestasi Belajar Biologi Ditinjau Dari Inteligensi Siswa SMA Negeri 1 Srono. Jurnal Pendidikan IPA Ghanesa, 3(1).

Putri, S. B., Sarwi \& Akhlis, I. (2018). Pembelajaran Inkuiri Terbimbing Melalui Kegiatan Lab Virtual dan Eksperimen Riil untuk Peningkatan Penguasaan Konsep dan Pengembangan Aktivitas Siswa. Unnes Physics Education Journal. 7(1). https://doi.org/10.15294/upej.v7i1.22477

Religia, R. (2017). Pengembangan KIT Sederhana Stirling Engine pada Materi Termodinamika sebagai Media Pembelajaran Fisika SMA. Jurnal Inovasi Pendidikan Fisika (JIPF). https://doi.org/10.26740/ipf.v6n3.p\%25p

Rohwati, M. (2012). Penggunaan Education Game Untuk Meningkatkan Hasil Belajar IPA Biologi Konsep Klasifikasi Makhluk Hidup. Jurnal Pendidikan IPA Indonesia, 1(1). http://dx.doi.org/10.15294/jpii.v1i1.2017

Rumansyah, R., Kosim, K., \& Soeprianto, H. (2016). Pengembangan Model Pembelajaran Kooperatif Tipe Kosaji Pada Pembelajaran Fisika. Jurnal Penelitian Pendidikan IPA, 2(2). https://doi.org/10.29303/jppipa.v2i2.42

Sari, R. P., Mauliza, M., Nazar, M., \& Nahadi, N. (2020). The Implementation of Performance Assessment Through Virtual Laboratory to College Students' Creative Thinking Skills. Jurnal Penelitian Pendidikan IPA,7(1), Retrieved from: https://doi.org/10.29303/jppipa.v7i1.484

Siswadi, S., Susilawati, S., \& Hikmawati, H. (2016). Pengaruh Pendekatan Vak (Visualization, Auditory, Kinestetic) Terhadap Hasil Belajar Fisika Siswa Smpn 10 Mataram Tahun Ajaran 2013/2014. Jurnal Penelitian Pendidikan IPA, 2(2). https://doi.org/10.29303/jppipa.v2i2.44

Supurwoko, S. (2017). Virtual Lab Experiment: Physics Educational Technology (Phet)Photo-Electric Effect for Senior High School. International Journal of
Science and Applied Science: Conference Series, 2(1). http://dx.doi.org/10.20961/ijsascs.v2i1.16750

Yusuf, I., \& Subaer, S. (2013). Pengembangan Perangkat Pembelajaran Fisika Berbasis Media Laboratorium Virtual Pada Materi Dualisme Gelombang Partikel Di Sma Tut Wuri Handayani Makassar. Jurnal Pendidikan IPA Indonesia, 2(2). https://doi.org/10.15294/jpii.v2i2.2722 